\title{
Substrate treatment for the increment of electric power potential from plants microbial fuel cells
}

\author{
Melisa Acosta-Coll ${ }^{1}$, Adalberto Ospino-Castro ${ }^{2}$, Stalin Carbonell-Navarro ${ }^{3}$, Jaider Escobar-Duque ${ }^{4}$, \\ Rafael Peña-Gallardo ${ }^{5}$, Ronald Zamora-Musa ${ }^{6}$ \\ ${ }^{1,2,3,4}$ Facultad de Ingeniería, Universidad de la Costa, Colombia \\ ${ }^{5}$ Facultad de Ingeniería, Universidad San Luis de Potosí, Mexico \\ ${ }^{6} \mathrm{Facultad}$ de Ingeniería, Universidad Cooperativa de Colombia, Colombia
}

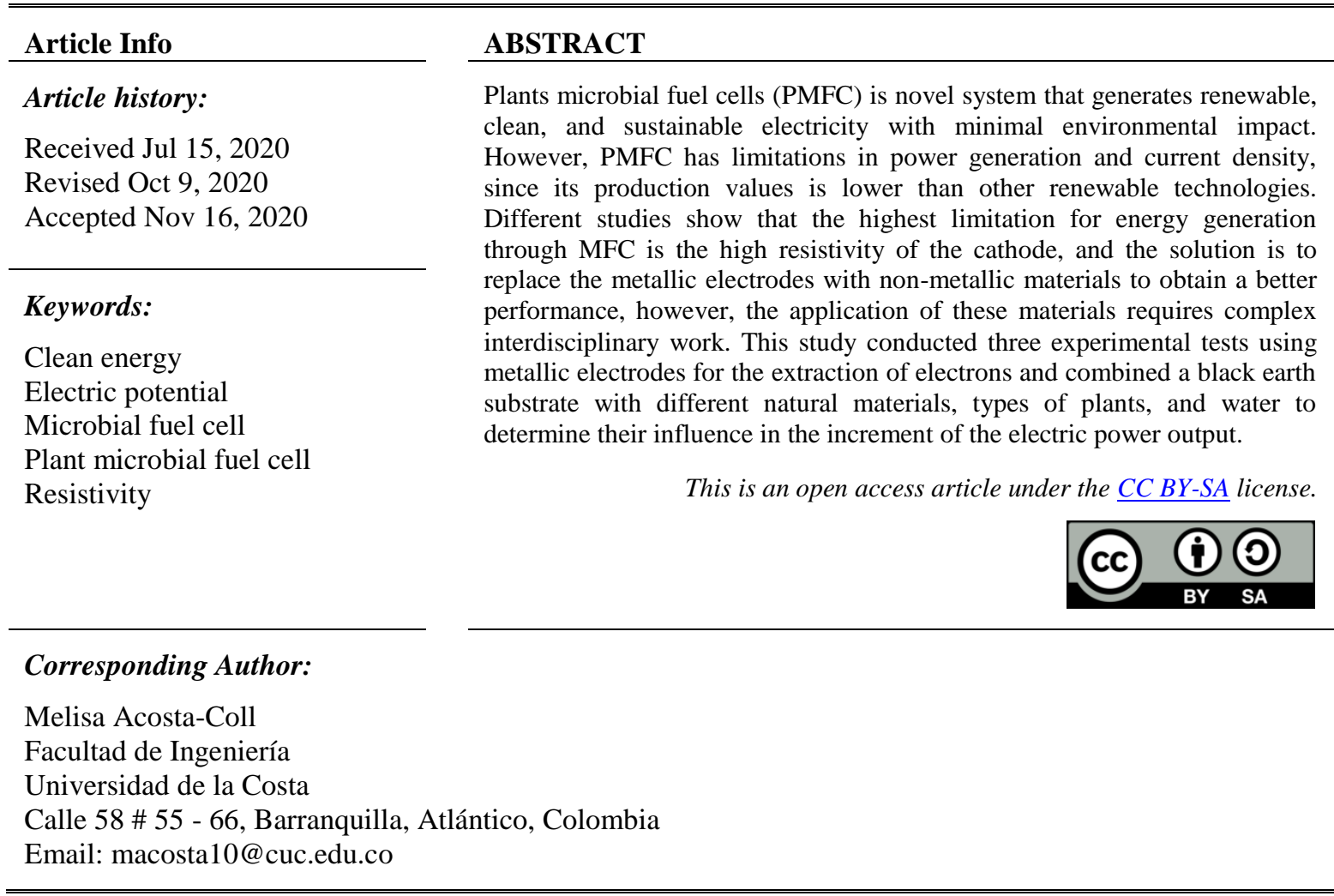

\section{INTRODUCTION}

The growing demand for energy and the effects of climate change related to greenhouse gas (GHG) emissions from fossil fuels have encouraged the search for alternatives to produce sustainable and reliable electricity, with minimal environmental impact [1-4]. One of these alternatives for the generation of electrical energy without the emission of contaminants has been the implementation of microbial fuel cells (MFC) [5, 6]. MFC uses microorganisms for the oxidation of organic matter and substrates of the surface through a process of anaerobic respiration to generate bioelectricity [7]. However, power generation and current density from MFC is lower compared to other non-conventional energy sources [8]. To improve the bioelectricity generation with MFC emerged a new method named plants microbial fuel cell (PMFC). PMFC uses the bacterial actions in plants' rhizosphere to transform solar radiation into electricity [9, 10]. To extract the electrons, the anode is placed next to the roots and transfer to the cathode through oxygen reduction $[11,12]$.

This method can generate continuous energy and operate at any location; however, there are some challenges in power generation that need to be overcome before its application [13, 14]. One factor that most affects the generation capacity of this technology is the electrode material, which must have good electrical conductivity and low resistance $[15,16]$. Since cathodes have high internal resistance, different materials 
have been used to maximize its generation capacity. Table 1 presents a summary with non-metallic materials used to improve cathode efficiency and obtain more power $\left(\mathrm{W} / \mathrm{m}^{2}\right)$, current $(\mathrm{mA})$, and voltage $(\mathrm{mV})[17,18]$.

Table 1. Non-metallic materials used to improve cathode efficiency

\begin{tabular}{cccc}
\hline Material & Max power density & Max current density & Max voltage \\
\hline Activated carbon fiber felt (ACFF) & $0.315 \mathrm{~W} / \mathrm{m}^{2}$ & $1.67 \times 10^{-3} \mathrm{~mA} / \mathrm{m}^{2}$ & $679 \mathrm{mV}$ \\
Tubular (ACFF) & $0.784 \mathrm{~W} / \mathrm{m}^{2}$ & $3170 \mathrm{~mA} / \mathrm{m}^{2}$ & $716 \mathrm{mV}$ \\
Graphite felt & $0.539 \mathrm{~W} / \mathrm{m}^{2}$ & $3145 \mathrm{~mA} / \mathrm{m}^{2}$ & $742.3 \mathrm{mV}$ \\
ACFF granules $(1 \mathrm{~cm})$ & $0.667 \mathrm{~W} / \mathrm{m}^{2}$ & $3340 \mathrm{~mA} / \mathrm{m}^{2}$ & $658 \mathrm{mV}$ \\
\hline
\end{tabular}

The University of Engineering and Technology (UTEC) used a different technique to increase PMFC power generation, capturing the electricity through a group of microorganisms called Geobacter. These anaerobic bacteria help to release electrons through electrodes located in the plant's substrate to increment the power output [19]. Other studies implemented different methods to improve bioelectricity generation, like the use of different types of plants [20] the variation of anode position concerning the distance of the roots [21], as well as the study of the effect of sunlight on the generation of bioelectricity [22]. Also, European institutes work towards a maximum electrical production of $3 \mathrm{~W} / \mathrm{m}^{2}$ [23]. This research proposes a new method to improve the generation of bioelectricity production through plants microbial fuel cells (PMFC) by combining different natural materials, tropical plants, and circuit arrangements in a black earth substrate using metal electrodes made of aluminum and copper. Three tests were developed to determine the combination leading to higher generation capacity, without causing damage to the plant.

\section{METHODOLOGY}

\subsection{Experimental setup}

To determine the combination that generates the highest power output without damaging the plant, three tests were conducted combining materials such as plants, activated carbon, charcoal, saline, seawater, and compost. The three tests used black earth substrates as a base, and for the extraction of electrons, it introduced a metallic aluminum into the substrate, as the negative pole, and a spiral of bare copper wire, as the positive pole.

Each combination is built by following the next steps: first, add a layer of black earth substrate moistened with drinking water to the base of the pot. Second, place the aluminum mesh on the first layer of the substrate as a negative post. Third, add the second layer of the substrate to the mesh and insert a copper coil, which is the positive pole. Finally, place another layer of black earth substrate and sow the plants. Figure 1 shows the circuit diagram used for each combination.

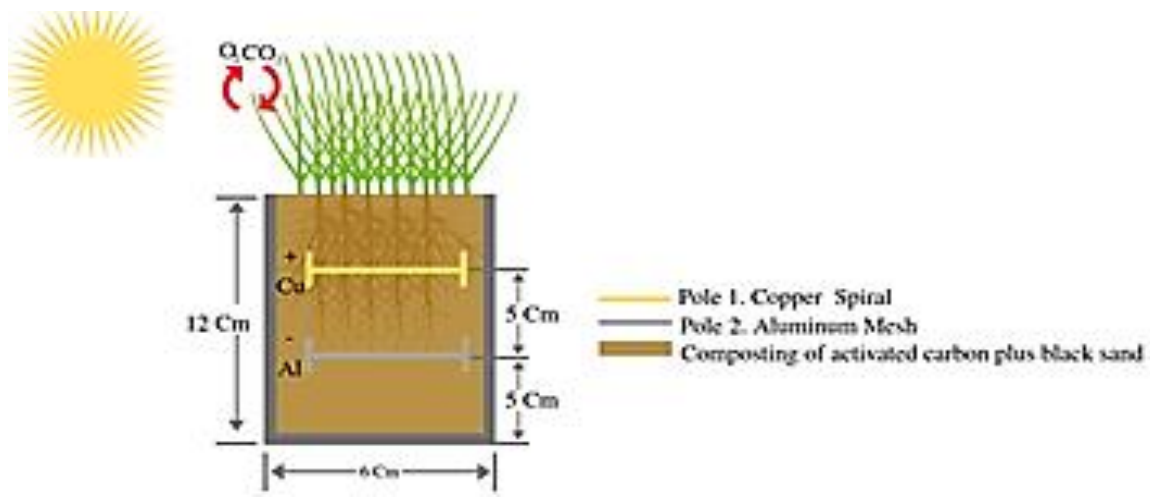

Figure 1. Circuit design for each combination

\subsection{Tests}

\subsubsection{Test 1: voltage measurement}

The first test combined Chlorophytum comosum plants and black earth substrate with natural materials such as activated charcoal, charcoal, and saline solution to identify which combination generates the highest electrical potential, without causing damage to the plants. Five different combinations were 
created and measured the voltage with a 24-hour interval. Table 2 shows the combinations. Table 3 shows materials used for each combination and the amount of substrate and water.

Table 2. Combinations of the black earth substrate with plants

\begin{tabular}{cc}
\hline Combinations & Materials \\
\hline 1 & Black earth + water+plants \\
2 & Black earth + activated charcoal+ water+plants \\
3 & Black earth + charcoal+ water+plants \\
4 & Black earth+activated charchoal+saline solution+plants \\
5 & Black earth+saline solution+plants \\
\hline
\end{tabular}

Table 3. Materials used in the combinations

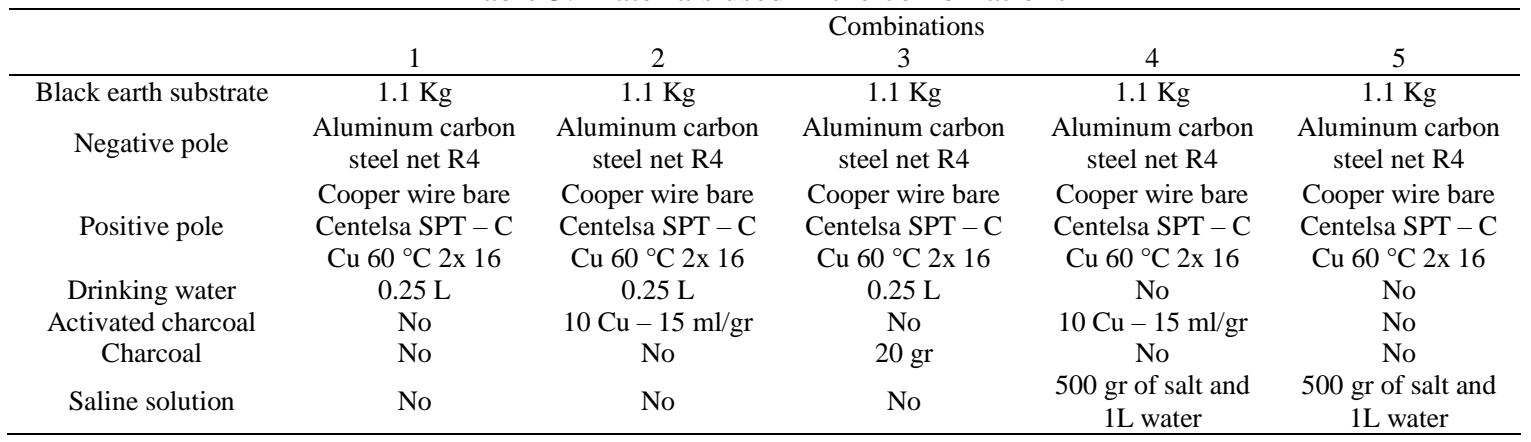

The activated carbon used in combinations 2 and 4 has an internal porous structure that helps reach high absorption rates and storing electrical charges, with high electrical conductivity [24, 25]. Combinations three and four used charcoal with the black earth substrate and plants to determine its influence in voltage increment, considering it is a frequently used fertilizer to improve crop productivity. This material helps to increase the soil permeability by retaining moisture and contributes to the growth of microorganisms that increases oxygen in the roots of plants [26, 27]. Since in solutions with higher salinity, the number of dissolved ions is more considerable and thus increases their conductivity, combinations four and five added a saline solution instead of water to the black earth substrate [28, 29].

\subsubsection{Test 2: Voltage increment}

With the selected combination that generates higher voltage and does not cause deterioration in the plants, two circuits were built to increase the electrical potential and measured the voltage during eight days with a 24 hours interval. The first circuit connected five pots in series (model 1) using the combination selected in test 1 . This design is based on Kirchhoff's second Law of electrical circuits, where the sum of all voltages in a closed circuit must equal zero, and the current remains constant [30]. Figure 2 illustrates the series circuit structure with the pots.

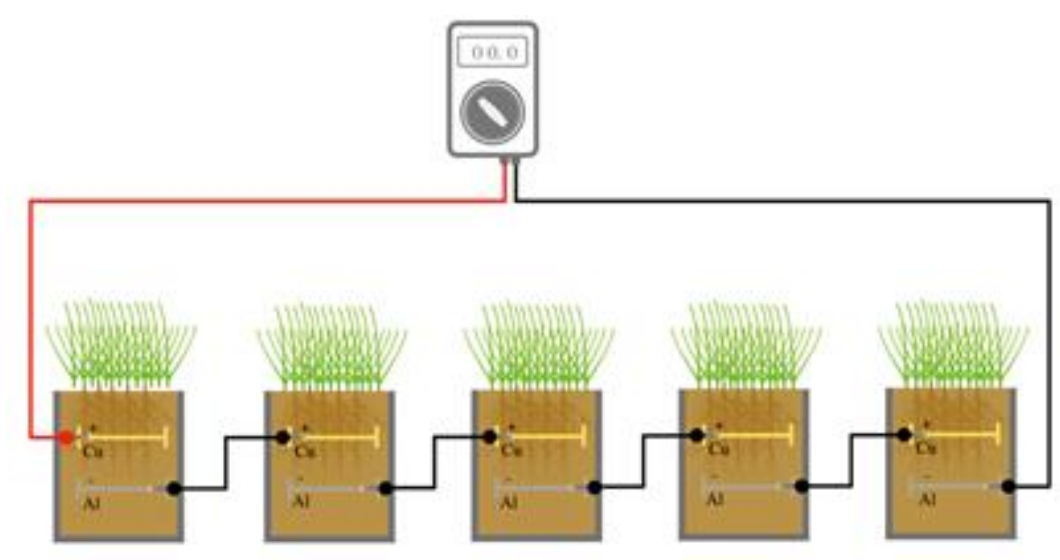

Figure 2. Series circuit connection 
The second circuit studied the influence of root volume in the electrical potential generation and combined three types of plants often called spider plant or ribbon plant, purple secretia or purple queen, and elephant ear in a bigger pot than model 1. For circuit one and two, the plant humidity was measured and controlled every 30 hours and voltage a 24-hour interval for eight days. Figure 3 shows the pot (model 2) with a combination of different plants.

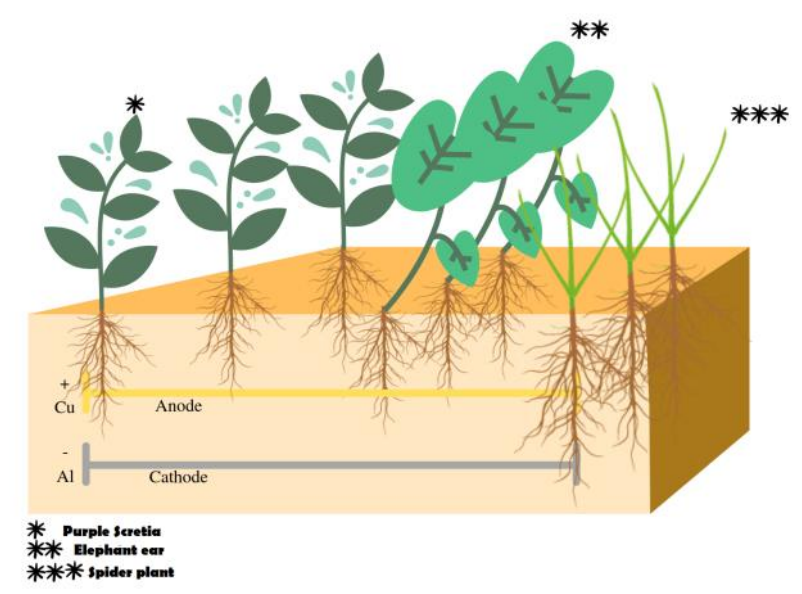

Figure 3. Pot with different plants (model 2)

\subsubsection{Test 3: Power generation increment}

To increase the current and maintaining the obtained voltage, in test 3 were built three new combinations from the results of test 2 combining materials such as compost, warm water, and seawater. Table 4 gathers the combinations made. In this test for five days, $250 \mathrm{ml}$ of three types of water were added, and measured the voltage and current produced by each combination.

The compost is formed by the decomposition of organic products that helps to fertilize the substrate and obtain a higher concentration of organic matter to increase the collected current at the electrodes [31, 32]. Combination 2 of Test 3 used warm water (drinking water at $45{ }^{\circ} \mathrm{C}-50{ }^{\circ} \mathrm{C}$ ) as it helps to accelerate the metabolic rates of aquatic organisms and helps to maintain the temperature balance between the environment and the substrate $[22,33]$. Combination 3 changed drinking water by seawater since it has more properties due to its high salinity and $\mathrm{pH}$ levels, as well as many minerals [34, 35].

Table 4. Combinations used for an increase in the current

\begin{tabular}{cc}
\hline Combinations & Materials \\
\hline 1 & Black earth + water+compost+plants \\
2 & Black earth + warm water+ plants \\
3 & Black earth + seawater+ plants \\
\hline
\end{tabular}

\section{RESULTS}

\subsection{Voltage measurement}

Using aluminum and copper electrodes, when combining the black earth substrate and plants with materials such as activated carbon, charcoal, and solution, voltage values higher than $490 \mathrm{mV}$ were obtained. Figure 4 presents the results of the voltage measurements of the combinations of Table 2. The combination "1" (black earth + potable water + plants) obtained the highest voltage, followed by the combination 2 (black earth + active carbon + potable water + plants). Conversely, the combination 4 (black earth + active carbon + saline + plants) obtained the lowest voltage value. Taking into account the state of the plant, combinations 1, 2, 3 and 4 did not show signs of deterioration; however, although it obtained a higher voltage value than in combination 4, the plant deteriorated completely in combination 5 (black s earth + saline + plants). Therefore, the combination " 1 " was selected to perform the voltage and current increase tests. The saline solution is discarded for future tests since it generates total deterioration in the plants. For voltage measurement, electrodes must be distant from each other to obtain a measure without variations, since there are distortions when they are close. 


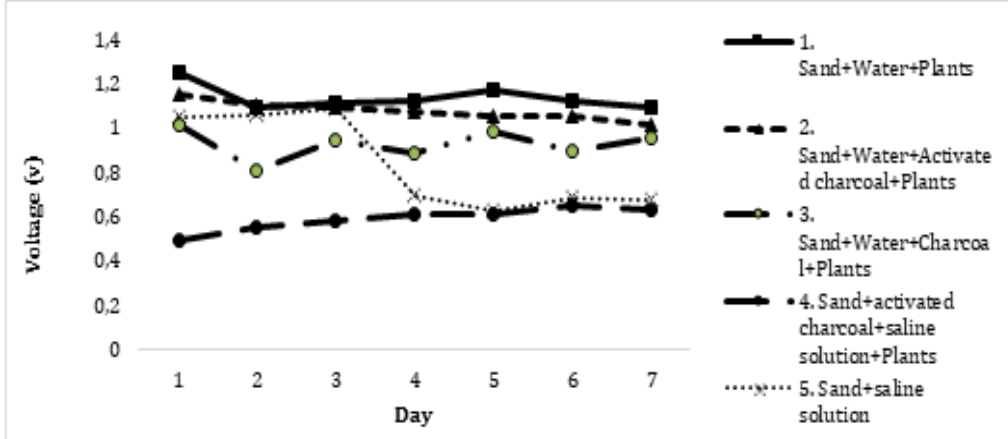

Figure 4. Results of voltage measurement

\subsection{Voltage increment}

Figure 5 presents the results of test 2 to increase the voltage comparing the series circuit and the circuit with different types of plants with higher number of roots. According to the test 2 results, the circuit formed by different plants and with higher number of roots per square meter obtained the highest increment in voltage. The above shows that the generation of energy does not depend only on the type of plant, but that the plant has the necessary nutrients to carry out the photosynthetic process, in the same way, the greater the number of roots, the greater the generation of electrical energy.

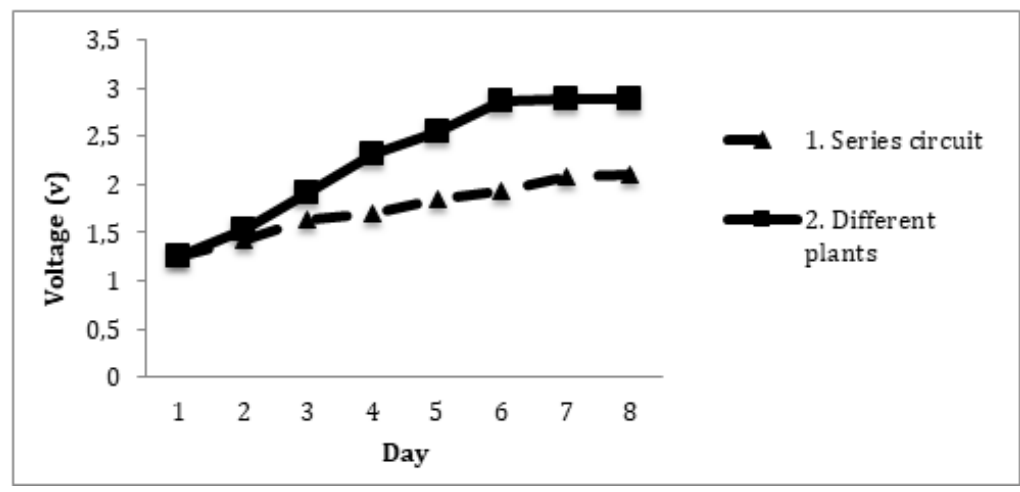

Figure 5. Results of voltage increment

\subsection{Power generation increment}

Figures 6 and 7 compare the voltage and current results of power generation increment of test 3 . Compost, warm water, and seawater were added to a circuit with a higher number of Chlorophytum comosum roots considering that the voltage is proportional to the number of roots per square meter. Figure 6 shows that the circuit with warm water obtained the highest level of voltage during days 2,3 , 4, and 5; but in day 1 registered the lowest. Although the circuit with compost did not obtain the highest voltage value, these were constant. Conversely, the circuit with seawater recorded the lowest voltage values but during day 1 had a higher value than seawater combination.

Regarding the current, the circuit that generated the highest levels was that of seawater, but the plant showed deterioration in its leaves as shown in Figure 7. The compost circuit only recorded current on days 4 and 5, but obtained the lowest values. Figure 8 shows the results for the output power obtained in this test expressed in $\mathrm{W} / \mathrm{m}^{2}$.

The power output results from Figure 8 show that the combination of the black earth with more roots and warm water recorded the highest values with a power generation range of $0.065-0.524 \mathrm{~W} / \mathrm{m} 2$. Regarding the plant conditions, this combination did not cause damage to the plants. The above is since most biological processes are accelerated at high temperatures, achieving rapid growth or fruit production [36-38]. However, the temperature should not be too high to avoid deterioration or death of the plant [39]. Table 5 presents a summary of the maximum electrical potential difference obtained in each test. Likewise, the current value and maximum power obtained in test 3 that did not cause deterioration to the plant. 
Through the development of these experiments, we can demonstrate that the efficiency of the cathode is as decisive as the number of roots per square meter. Likewise, the humidity and temperature of the substrate influence the increment of bioelectricity generation power output using the PMFC method.

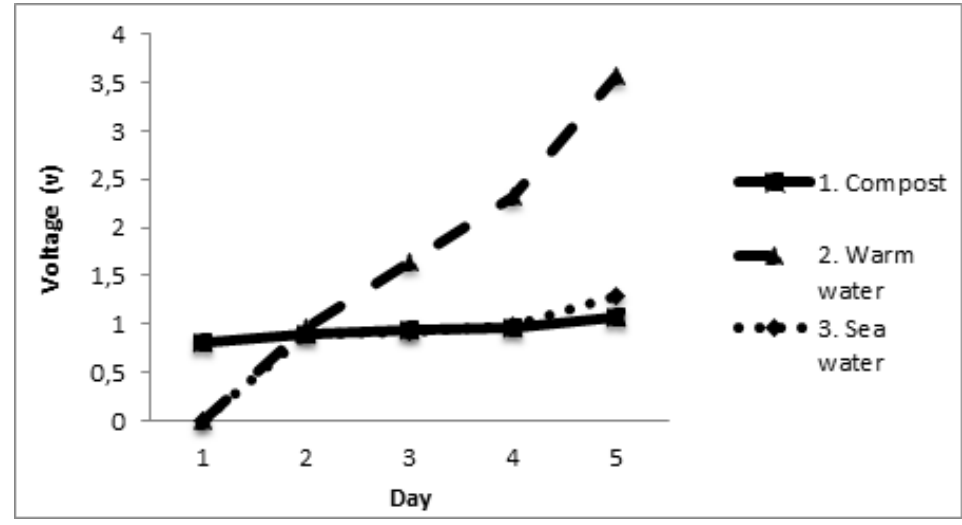

Figure 6. Voltage values of power generation increment

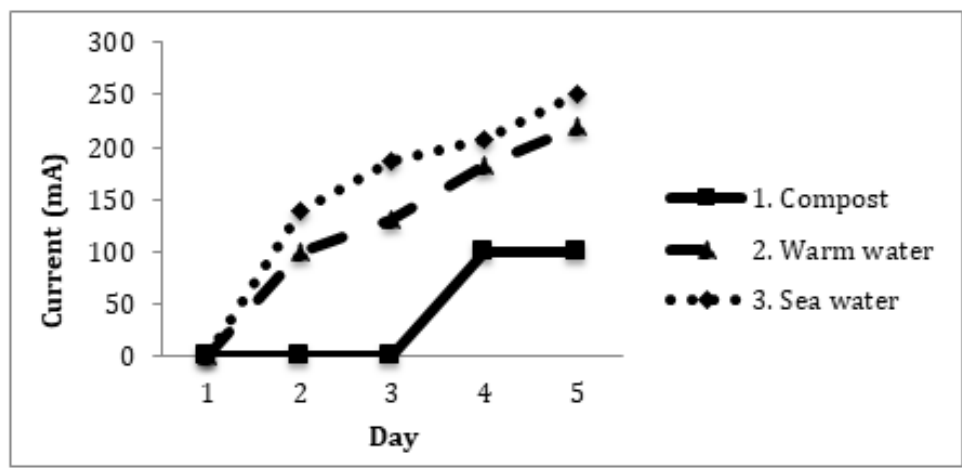

Figure 7. Current values of power generation increment

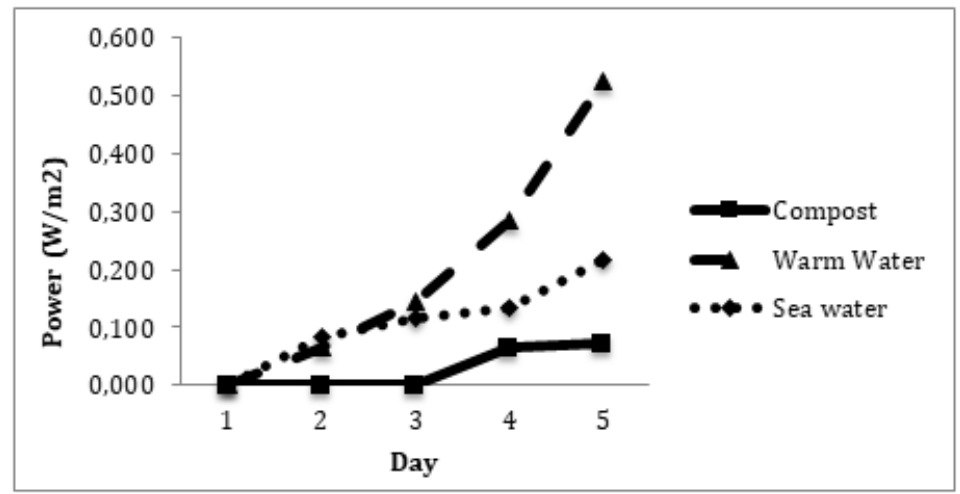

Figure 8. Power output

Table 5. Maximum voltage values

\begin{tabular}{cccc} 
& Test & Test 2 & Test 3 \\
& Black earth+plantas+water & Different plants & Black earth+more plants+warm water \\
\hline Max. Voltage $(\mathrm{V})$ & 1.09 & 2.89 & 3.57 \\
Max. Current $(\mathrm{mA})$ & N/A & N/A & 220 \\
Max. Power $\left(\mathrm{W} / \mathrm{m}^{2}\right)$ & N/A & N/A & 0.524 \\
\hline
\end{tabular}




\section{CONCLUSION}

This research developed different tests to increase the power of electric power generation through the plants microbial fuel cells (PMFC) method. The tests designed different types of circuits combining natural materials in the substrate and of plants. The results showed that generating electricity through PMFC is directly associated with the number of roots plants because it will accelerate the excretion of organic compounds from the roots and produce a higher concentration of microbial activity and hence increment of bioelectricity generation. Also, maintaining temperatures just above room temperature contributes to the increment in electrical conductivity without damaging the plant. Similarly, seawater and saline solutions reached higher electric current levels; however, it is not appropriate as they cause death or deterioration of plants.

\section{REFERENCES}

[1] M. Acosta-Coll et al., "Real-time early warning system design for pluvial flash floods-A review," Sensors, vol. 18, p. 2255, Jul. 2018

[2] J. Cabello et al., "Bridging universities and industry through cleaner production activities. Experiences from the Cleaner Production Center at the University of Cienfuegos, Cuba," Journal of cleaner production, vol. 108, pp. 873-882, Dec. 2015.

[3] S. Oncel, "Green energy engineering: Opening a green way for the future," Journal of cleaner production, vol. 142, pp. 3095-3100, Jan. 2017.

[4] C. Robles-Algarín et al., "Procedimiento para la Selección de Criterios en la Planificación Energética de Zonas Rurales Colombianas," Información tecnológica, vol. 29, pp. 71-80, Jun. 2018.

[5] M. Rahimnejad et al., "Microbial fuel cell as new technology for bioelectricity generation: A review," Alexandria Engineering Journal, vol. 54, pp. 745-756, Sep. 2015.

[6] A. Franks and K. Nevin, "Microbial fuel cells, a current review," Energies, vol. 3, pp. 899-919, Apr. 2010.

[7] C. Santoro et al., "Microbial fuel cells: from fundamentals to applications. A review," Journal of power sources, vol. 356, pp. 225-244, Jul. 2017.

[8] S. Flimban et al., "Overview of recent advancements in the microbial fuel cell from fundamentals to applications: design, major elements, and scalability," Energies, vol. 12, p. 3390, Sep. 2019.

[9] A. Nandy et al., "Comparative evaluation of coated and non-coated carbon electrodes in a microbial fuel cell for treatment of municipal sludge," Energies, vol. 12, p. 1034, Mar. 2019.

[10] R. Regmi et al., "A decade of plant-assisted microbial fuel cells: looking back and moving forward," Biofuels, vol. 9, pp. 605-612, Feb. 2018.

[11] K. Aiyer, "How does electron transfer occur in microbial fuel cells?" World Journal of Microbiology and Biotechnology, vol. 36, p. 19, Jan. 2020.

[12] M. Rossi et al., "Let the microbes power your sensing display," 2017 IEEE Sensors, pp. 1-3, Nov. 2017.

[13] M. Vanitha et al., "Microbial fuel cell characterisation and evaluation of Lysinibacillus macroides MFC02 electrigenic capability," World Journal of Microbiology and Biotechnology, vol. 33, p. 91, Apr. 2017.

[14] B. Logan et al., "Microbial fuel cells: methodology and technology," Environmental science \& technology, vol. 40, pp. 5181-5192, Jul. 2006.

[15] G. Chen et al., "Application of biocathode in microbial fuel cells: cell performance and microbial community," Applied microbiology and biotechnology, vol. 79, pp. 379-388, Jun. 2008.

[16] F. Offei et al., "A viable electrode material for use in microbial fuel cells for tropical regions," Energies, vol. 9, p. 35, Jan. 2016.

[17] Q. Deng et al., "Power generation using an activated carbon fiber felt cathode in an upflow microbial fuel cell," Journal of Power Sources, vol. 195, pp. 1130-1135, Feb. 2010.

[18] A. Ter Heijne et al., "A bipolar membrane combined with ferric iron reduction as an efficient cathode system in microbial fuel cells," Environmental science \& technology, vol. 40, pp. 5200-5205, Jul. 2006.

[19] K. Vezina, "Plant Lamps" Turn Dirt and Vegetation into a Power Source," MIT Technology Review [Online]. Available: https://declara.com/content/OgeWo67a.

[20] P. Sarma and K. Mohanty, "Epipremnum aureum and Dracaena braunii as indoor plants for enhanced bioelectricity generation in a plant microbial fuel cell with electrochemically modified carbon fiber brush anode," Journal of bioscience and bioengineering, vol. 126, pp. 404-410, Sep. 2018

[21] B. Liu et al., "Anodic potentials, electricity generation and bacterial community as affected by plant roots in sediment microbial fuel cell: Effects of anode locations," Chemosphere, vol. 209, pp. 739-747, Oct. 2018.

[22] Y. Hubenova and M. Mitov, "Conversion of solar energy into electricity by using duckweed in direct photosynthetic plant fuel cell," Bioelectrochemistry, vol. 87, pp. 185-191, Oct. 2012.

[23] M. Helder et al., "Electricity production with living plants on a green roof: environmental performance of the plantmicrobial fuel cell," Biofuels, Bioproducts and Biorefining, vol. 7, pp. 52-64, Jan. 2013.

[24] R. Moliner, "Del carbón activo al grafeno: Evolución de los materiales de carbon," Boletín del Grupo Español del Carbón, vol. 41, pp. 2-5, Sep. 2016.

[25] M. Richard, "El carbón activo ya se fabrica con una estructura diseñada a medida," MIT Technology Review [Online]. Available: https://www.technologyreview.es/s/4951/el-carbon-activo-ya-se-fabrica-con-una-estructuradisenada-medida. 
[26] P. Omo-Okoro et al., "A review of the application of agricultural wastes as precursor materials for the adsorption of per-and polyfluoroalkyl substances: a focus on current approaches and methodologies," Environmental Technology \& Innovation, vol. 9, pp. 100-114, Feb. 2018.

[27] K. Palansooriya et al., "Impacts of biochar application on upland agriculture: A review," Journal of environmental management, vol. 234, pp. 52-64, Mar. 2019.

[28] J. Kamcev et al., "Salt concentration dependence of ionic conductivity in ion exchange membranes," Journal of Membrane Science, vol. 547, pp. 123-133, 2018.

[29] C. Yuan et al., "Effects of deficit irrigation with saline water on soil water-salt distribution and water use efficiency of maize for seed production in arid Northwest China," Agricultural water management, vol. 212, pp. 424-432, Feb. 2019.

[30] C. Alexander, Fundamentals of electric circuits. McGraw-Hill, 2009.

[31] J. Frouz, "Effects of soil macro-and mesofauna on litter decomposition and soil organic matter stabilization," Geoderma, vol. 332, pp. 161-172, Dec. 2018.

[32] S. Rostami and A. Azhdarpoor, "The application of plant growth regulators to improve phytoremediation of contaminated soils: A review," Chemosphere, vol. 220, pp. 818-827, Apr. 2019.

[33] R. Piyare et al., "Plug into a plant: Using a plant microbial fuel cell and a wake-up radio for an energy neutral sensing system," 2017 IEEE 42nd Conference on Local Computer Networks Workshops, Nov. 2017, pp. 1-4.

[34] G. Atzori et al., "Seawater potential use in soilless culture: A review," Scientia Horticulturae, vol. 249, pp. 199-207, Apr. 2019.

[35] S. Yang et al., "Performance modelling of seawater electrolysis in an undivided cell: Effects of current density and seawater salinity," Chemical Engineering Research and Design, vol. 143, pp. 79-89, Mar. 2019.

[36] F. Canna, "Influencia de la temperatura ambiental en las plantas," CANNA Research [Online]. Available: http://www.canna.es/influencia_temperatura_ambiental_en_las_plantas.

[37] O. Olubode, "Influence of seasonal variability of precipitation and temperature on performances of pawpaw varieties intercropped with cucumber," Scientia Horticulturae, vol. 243, pp. 622-644, Jan. 2019.

[38] M. Benlloch-González et al., "Effect of moderate high temperature on the vegetative growth and potassium allocation in olive plants," Journal of plant physiology, vol. 207, pp. 22-29, Dec. 2016.

[39] J. Ni et al., "Effects of vegetation on soil temperature and water content: Field monitoring and numerical modeling," Journal of Hydrology, vol. 571, pp. 494-502, Apr. 2019.

\section{BIOGRAPHIES OF AUTHORS}

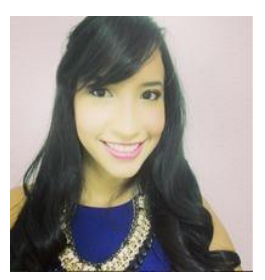

Melisa Acosta Coll is a professor at Universidad de la Costa in the Computer Science and Electronic department with participation in teaching and research processes in the areas applied electromagnetics, telecommunications, bioengineering, and research methodology. His experience includes managing research projects developed in cooperation with Colombian and foreign, institutions, and universities. His outcomes include several research articles published in high impact international journals.

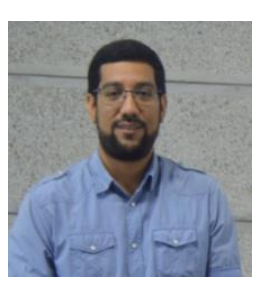

Adalberto Ospino Castro is a full-time professor at Universidad de la Costa, with participation in teaching and research processes in the areas of renewable energy, energy efficiency, and energy management. His experience includes managing research projects developed in cooperation with Colombian and foreign, institutions, and universities. His outcomes include several research articles published in high impact international journals.

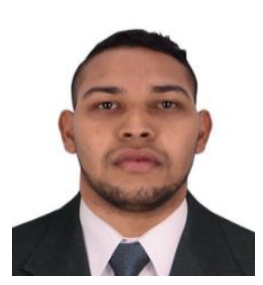

Stalin Jose Carbonell Navarro Electrical Engineer from the Universidad de la Costa. His research interests include power generation and control of power systems. Currently linked in the electrical energy works sector.

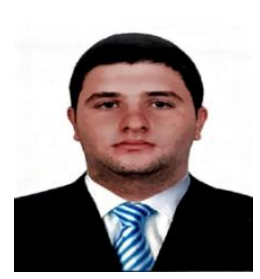

Jaider Emilio Escobar Duque-Electrical Engineer from the Universidad de la Costa. Work experience in the area of Telemetry. His research interests are in the area of renewable energy and sustainable growth. 


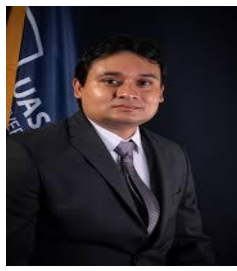

Rafael Peña G., Ph.D. in Electric Power Systems, Universidad Michoacana de San Nicolas de Hidalgo, Mexico, Full Time Teacher-Researcher, Universidad Autonoma de San Luis Potosi, Mexico, fields of Competence, Modeling, control and analysis of distributed generation systems based on renewable energy. His outcomes include several research articles published in high impact international journals.

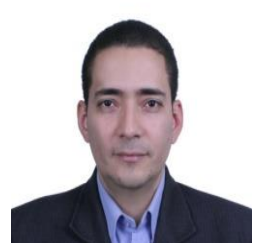

Ronald Zamora-Musa is a Research Professor of Engineering at the "Universidad Cooperativa de Colombia" in Barrancabermeja, Santander. His research covers innovation and new technology; he is interested in renewable energy, IT applications, and collaborative and immersive environments. $\mathrm{He}$ is a candidate for a Ph.D. in Engineering with MSc Engineering, and he is an Electronics and Telecommunications Engineer. 